HortSCIENCE 26(4):428-429. 1991.

\section{'Sunblaze' Nectarine}

\section{W.B. Sherman, P.M. Lyrene, and F.G. Gmitter \\ Fruit Crops Department, University of Florida, Gainesville, FL 32611}

'Sunblaze' nectarine, Prunus persica (L.) Batsch, produces an attractive, high quality, yellow-flesh fruit recommended for commercial and homeowner trial in Florida, where 'Sunred' nectarine has been grown successfully. All nectarine cultivars released by the Univ. of Florida Agricultural Experiment Station begin with the prefix "Sun". The suffix "blaze" indicates the rich, red skin pigmentation of the fruit. 'Sunblaze' is expected to replace 'Sunred' because it blos-

Received for publication 22 Aug. 1990. Florida Agricultural Experiment Station Journal Series no. R-00924. The cost of publishing this paper was defrayed in part by the payment of page charges. Under postal regulations, this paper therefore must be hereby marked advertisement solely to indicate this fact. colder locations in the absence of spring frost.

Fruit of 'Sunblaze' have been observed on budded trees since 1981. The following description of fruit and tree characteristics summarizes observations for 9 fruiting years on trees 2 to 7 years old. Trees are semispreading and respond favorably to pruning, which permits the formation of an open center. Flower bud set is moderately heavy and trees require moderate fruit thinning in the absence of thinning by spring frosts.

Major advantages of 'Sunblaze' are increased fruit firmness and size over 'Sunred', and resistance to bacterial spot [Xanthomonas campestris pv. pruni (Smith) Dye]. Fruit are moderately large for the maturity season, averaging $\approx 6 \mathrm{~cm}$ in diameter and $100 \mathrm{~g}$. Thinning to space fruit 15 to $20 \mathrm{~cm}$ apart is required for proper sizing. Fruit ripen $\approx 90$ days from bloom. 'Sunblaze' ripens $\approx 10$ to 12 days after 'Flordaprince' peach, and at the same time as 'Sunred' nectarine, for which it is a replacement. Fruit are slightly oval with no sharp tip or suture bulge, firm, ripen evenly throughout the flesh, and are semifree with separation of the pit and flesh when soft ripe. Flesh is yellow and melting and,

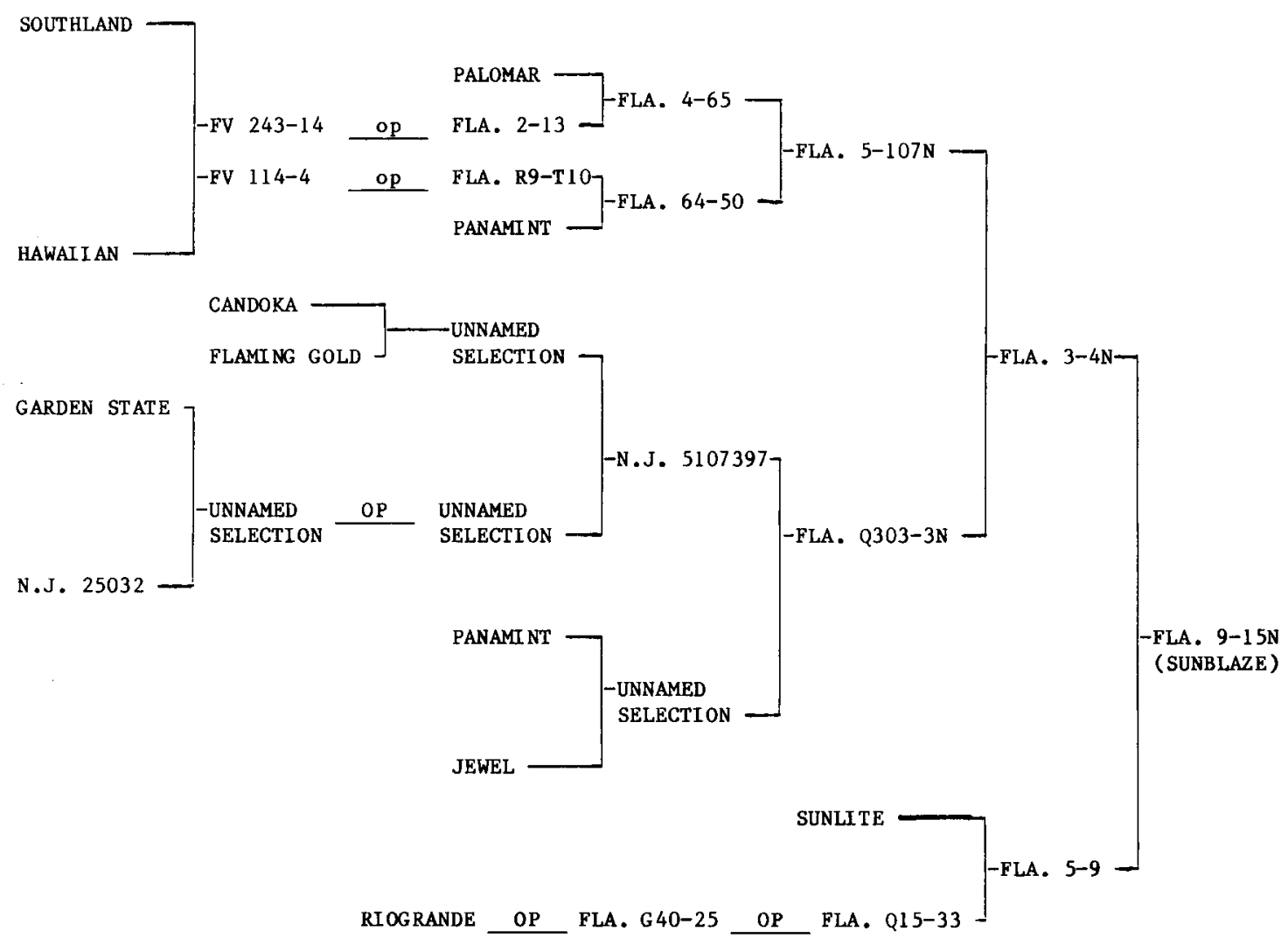

Fig. 1. Pedigree of 'Sunblaze' nectarine ( $\mathrm{OP}=$ open pollinated). 
in our opinion, with good dessert quality and flavor as found in 'Sunred' nectarine. The skin is relatively free of sugar speckles, compared to 'Sunripe' nectarine. Flesh browning does not occur readily on cut or bruised surfaces. Pits are medium small and have a low tendency to split during fruit development. External fruit appearance is similar to 'Sunlite' nectarine, with $90 \%$ to $100 \%$ deep red blush over a yellow ground color. The harvest period, lasting 5 to 7 days, begins in mid-May in the best adapted area and is about a week later at Gainesville. Trees are vigorous and productive. Yields in the absence of frost damage are high. Leaves are medium in size with reniform petiolar glands. Leaves and fruit are resistant to bacterial spot, similar to 'Flordaking'. Flowers are non- showy and deep pink. Pollen is bright yellow and abundant. Trees are self-fertile and precocious, fruiting with commercial crops when 2 years old (third leaf in the field).

\section{Availability}

Budwood has been released to commercial nurseries, and limited quantities of budwood may be obtained from the Fruit Crops Dept. 